\title{
Stroke and risk factors for falls in elderly individuals
}

\author{
Acidente vascular cerebral e fatores de risco para quedas em idosos
}

Alice Gabrielle de Sousa Costa ${ }^{1}$, Ana Railka de Souza Oliveira-Kumakura ${ }^{2}$, Thelma Leite de Araujo ${ }^{3}$, Natália Barreto de Castro ${ }^{3}$, Viviane Martins da Silva ${ }^{3}$, Marcos Venícios de Oliveira Lopes ${ }^{3}$

Objective: to verify and compare the intrinsic and extrinsic risk factors for falls among older community-dwelling people with and without a stroke history. Methods: a case group and three control groups were established and each group had 15 elderly individuals. Results: the statistical associations were: use of antihypertensive medication among the groups with falls, despite the occurrence of a stroke; use of angiotensin-converting enzyme inhibitor for elderly with a stroke who had an event of fall or not; foot alterations between the case group and people without falls or stroke. Gait difficulty and impaired physical mobility were statistically associated between the case group and people without the occurrence of stroke or falls. Conclusion: the stroke is associated with falls and the intrinsic factors presented greater statistical correlations, supporting the hypothesis that many factors influence the occurrence of falls.

Descriptors: Accidental Falls; Risk Factors; Stroke.

Objetivo: verificar e comparar os fatores de risco intrínsecos e extrínsecos para quedas em idosos, com e sem acidente vascular cerebral. Métodos: estabeleceram-se três grupos controle e um grupo caso, com 15 idosos cada. Resultados: as associações estatísticas foram: uso de medicação anti-hipertensiva entre os grupos com quedas, apesar da ocorrência de acidente vascular cerebral; uso de inibidor da enzima conversora de angiotensina para pessoas idosas com acidente vascular cerebral que tiveram ou não queda; alterações nos pés entre o grupo caso e as pessoas sem quedas ou acidente vascular cerebral. A dificuldade de marcha e a mobilidade física prejudicada foram estatisticamente relevantes entre o grupo caso e as pessoas sem a ocorrência de acidente vascular cerebral ou quedas. Conclusão: o acidente vascular cerebral está associado a quedas e os fatores intrínsecos apresentaram maiores correlações estatísticas, apoiando a hipótese de que muitos fatores influenciam a ocorrência de quedas.

Descritores: Acidentes por Quedas; Fatores de Risco; Acidente Vascular Cerebral.

${ }^{1}$ OMNI College. Vancouver, BC, Canada.

${ }^{2}$ Universidade Estadual de Campinas. Campinas, SP, Brazil.

${ }^{3}$ Universidade Federal do Ceará. Fortaleza, CE, Brazil. 


\section{Introduction}

Falls are still the leading cause of death in the elderly population due to injuries, and it also contributes to a major cost to the healthcare system ${ }^{(1)}$. Falls typically have a multifactorial etiology, composed of intrinsic (e.g., poor balance, weakness, chronic illness, visual or cognitive impairment) and extrinsic (e.g., poor lighting, no safety equipment, loose carpets) factors $^{(2)}$.

In addition, many authors suggest that stroke is one of the most important risk factors for falls, since it aggravates the intrinsic conditions ${ }^{(3-4)}$. In this context, the stroke-related balance and gait deficits are important risk factors for falls. Elderly people that present these deficits have an increased risk for hip fractures, regain independent mobility less often, and develop a fear of falling as a consequence ${ }^{(5)}$. Individuals with stroke are also at high risk for falls in each of the post-stroke stages: acute, rehabilitative, and chronic phases ${ }^{(5)}$. Falls are clearly linked to strokes, and people with strokes fall more often than similarly aged individuals ${ }^{(3)}$, especially in the first six months following discharge from acute rehabilitation ${ }^{(4)}$. Nevertheless, this risk can be higher due to stroke occurrence as well as physiologic alterations due to the aging process $^{(6)}$. Since the majority of people who suffer a stroke are older people, this brings the hypothesis: the occurrence of falls is multifactorial in all groups of elderly people and a stroke episode can influence the increase of these factors, especially intrinsic ones and those related with physical conditions.

Understanding fall patterns and predictors of falls is an important nursing issue and identifying this problem is essential to stablish the care plan ${ }^{(4)}$. However, further research is needed to investigate the risk factors that lead to increased risk of falls after an episode of stroke ${ }^{(3)}$. Also, understanding these contributing factors and their characteristics can increase the possibility of addressing the priorities of the elderly population. Thus, nurses could work to minimize the risk for falls by conducting a multifactorial assessment that allows prompt evidence-based interventions ${ }^{(1)}$.

This study aimed to verify and compare the intrinsic and extrinsic risk factors for falls among older community-dwelling people with and without a stroke history, evaluating the existence of statistical associations.

To verify and compare the intrinsic and extrinsic risk factors for falls among older community-dwelling people with and without a stroke history.

\section{Methods}

This is a comparative study with a case and multiple control groups. The participants were recruited for convenience from two governmental institutions that develop physical or recreational activities for the elderly population. For the sample selection a snowball sampling technique was applied. All participants were aged 60 years or older and were registered in one of the institutions. Those with stroke and a fall episode in the last six months were selected for the case group (CAG). A number of 15 individuals fulfilled the criteria for the case group.

Then, three control groups were stablished according to the inclusion criteria: COG1: participants with stroke and without fall; CGO2: participants without stroke and with fall; and COG3: participants without stroke and without fall. Each group included 15 individuals who were paired by sex and age according to the case group and met the above-stated criteria.

In addition, only the falls that had occurred in the previous six months and following a stroke were considered. The episodes were mentioned by the patients or caregivers and in cases of more than one related fall in that period, only the extrinsic characteristics of the last one were collected.

The exclusion criteria included an inability to stand up, aphasia, blindness and impaired cognition characterized by the inability of understanding verbal communication and execute commands. Also, all the participants provided informed written consent and in cases of cognitive impairment, the consent was pro- 
vided by a legally authorized representative.

Data collection occurred in the institutions or at the participants' homes according to their availability and preferences. All measurements were completed on the same day by the same investigator, recording sociodemographic variables and risk factors for falls. A team composed of two nurses and five undergraduate nursing students were trained to collect all the data.

The data were collected using a form to record sociodemographic variables such as gender, age, people living with the participant, income and level of education. The form was pretested with six elderly people to adjust the questions to the study proposal. The pre-test indicated that some data needed to be added: specify the group that the participant matches, include information about the inability to perform any physical test, and add an assessment of the strength of the lower extremities. Small alterations were made to other questions to make them more understandable and to enhance the data collection.

Risk factors were based on those presented by the nursing diagnosis risk for falls from NANDA-I ${ }^{(7)}$. The extrinsic factors investigated were: time of day, location, lighting, conditions of the floor and shoes, clutter in the environment, anti-slip material in the bathroom, rugs, ramps, handrails and excess home furniture.

The intrinsic factors assessed were related to physical condition and included vision, use of medications or alcohol, cognition, functional activity, gait, balance, body mass index, muscle strength and feet conditions. These risk factors were assessed through scales and tests.

Grip strength was measured by a Saehan ${ }^{\circledR}$ hydraulic hand dynamometer. The participants were seated, with elbow flexed at a $90^{\circ}$ angle, and asked to squeeze, hold and release the dynamometer. The measurement was performed in both hands at three different times with intervals of 60 seconds, and the average of all the values was calculated. The muscle strength of the lower extremity was assessed by flex- ing or extending the extremities against a resistance and was scored according to a 5-point scale ${ }^{(8)}$.

The assessment of functional capacity was performed by the measurement of daily activities with the Barthel Index and Instrumental Activity of Daily Living Scale. The higher the score on these scales, the more independent the person is ${ }^{(9)}$.

Visual acuity was assessed through Snellen charts and different sizes of optotypes that scored from 0.1 to 1.0. A score equal to or less than 0.7 suggested impaired visual acuity. Although these charts are widely used, more studies are needed to determine their validity in elderly people who have had strokes.

Feet conditions were verified through inspection and palpation, looking for lesions or deformations. The performance-oriented mobility assessment investigated participants' gait and balance performance. The two-part scale includes a total balance score of 16 and total gait score of 12 , and a total score of less than 19 indicates a high risk for falls ${ }^{(10)}$.

In addition, the Mini-Mental State Examination evaluated the participant's cognitive state. This examination includes tests of orientation, attention, memory, language and visual-spatial skills scored according to the educational level ${ }^{(10)}$. The identification and classification of depression was measured by the short form of the geriatric depression scale, with 15 yes or no questions ${ }^{(11)}$.

The results were organized in Excel spreadsheets and analyzed using Predictive Analysis Software, version 18.0. The level of significance adopted was $5 \%(p<05)$. Because the groups were paired, they were considered dependent samples, and in this case, nonparametric statistical tests were used for the analysis. Thus, the Friedman test was applied to compare three or more groups when the variables did not show a normal distribution. The McNemar test analyzed the dichotomous variables of paired groups. The Shapiro-Wilk test was applied to test data normality, and the paired t-test was used to verify the difference of averages when the variables followed a normal dis- 
tribution. The Wilcoxon test was used to compare the median between two groups when the variables did not show a normal distribution.

The study complied with the formal ethical requirements set by national and international regulatory standards for research involving human beings.

\section{Results}

Each group had 10 women (66.7\%) and five men (33.3\%), and an average age was between 69 and 71 years old. Most participants were retired, had a partner, lived with family, earned a minimum wage and had a low education level, which ranged from $6.53( \pm 4.42)$ to $2.66( \pm 2.41)$ years of study. Regarding stroke, an average of 1.4 occurrences $( \pm 0.67)$ was reported over 5.6 years $( \pm 7.5)$. The fall data were similar between the groups and presented an average of 1.33 fall occurrences $( \pm 0.54)$ in an average of 2.45 months $( \pm 1.9)$ before data collection. In general, the groups including participants with stroke had worse physical conditions and were more functionally dependent than the groups without stroke, as presented in Table 1.

Table 1 - Percentage of the intrinsic risk factors

\begin{tabular}{lcccc}
\hline Variables & $\begin{array}{c}\text { Case } \\
\text { Group }\end{array}$ & $\begin{array}{c}\text { Control } \\
\text { Group 1 }\end{array}$ & $\begin{array}{c}\text { Control } \\
\text { Group 2 }\end{array}$ & $\begin{array}{c}\text { Control } \\
\text { Group 3 }\end{array}$ \\
\cline { 2 - 5 } & $\mathbf{n ( \% )}$ & $\mathbf{n ( \% )}$ & $\mathbf{n ( \% )}$ & $\mathbf{n ( \% )}$ \\
\hline Moderate dependency & $11(73.3)$ & $6(40.0)$ & $3(20.0)$ & $1(6.6)$ \\
Mild dependency & $2(13.3)$ & $4(26.6)$ & $6(40.0)$ & $5(33.3)$ \\
Partial dependence & $12(80.0)$ & $12(80.0)$ & $6(40.0)$ & $3(20.0)$ \\
Overweight & $7(46.6)$ & $7(46.6)$ & $7(46.6)$ & $6(40.0)$ \\
Obesity I & $3(20.0)$ & $2(13.3)$ & $1(6.6)$ & $2(13.3)$ \\
Mild depression & $8(53.3)$ & $7(46.7)$ & $2(13.3)$ & - \\
Cognitive impairment & $6(40.0)$ & $11(73.3)$ & $2(13.3)$ & - \\
Risk of falls & $9(60.0)$ & $5(33.3)$ & - & - \\
$\begin{array}{l}\text { Decreased strength in lower } \\
\text { extremities }\end{array}$ & $11(73.3)$ & $13(86.6)$ & $5(33.3)$ & $3(20.0)$ \\
Decreased visual acuity & $10(66.6)$ & $12(80.0)$ & $14(93.3)$ & $7(46.6)$ \\
\hline
\end{tabular}

Table 2 shows the risk factors for falls that presented statistical significance.

Table 2 - Statistically significant risk factors for falls among the case group and the control groups according to McNemar test

\begin{tabular}{lccc}
\hline Variables & $\begin{array}{c}\text { Case Group x } \\
\text { Control Group 1 }\end{array}$ & $\begin{array}{c}\text { Case Group } \\
\text { x Control } \\
\text { Group 2 }\end{array}$ & $\begin{array}{c}\text { Case Group } \\
\text { x Control } \\
\text { Group 3 }\end{array}$ \\
\hline Use of antihypertensive & 1.000 & 0.039 & 0.727 \\
$\begin{array}{l}\text { Use of angiotensin-converting } \\
\text { enzyme inhibitor }\end{array}$ & 0.008 & 0.453 & 0.625 \\
$\begin{array}{l}\text { Foot alterations } \\
\begin{array}{l}\text { Decreased strength in lower } \\
\text { extremities }\end{array}\end{array}$ & 0.063 & 0.289 & 0.016 \\
$\begin{array}{l}\text { Excess of home furniture } \\
\text { Gait difficulty }\end{array}$ & 0.344 & 0.065 & 0.021 \\
\begin{tabular}{l} 
Impaired physical mobility \\
\hline
\end{tabular} & 0.375 & 0.008 & 0.001 \\
\hline
\end{tabular}

Table 3 presents the tests and scales related to the physical conditions assessment that showed statistical associations among the groups. The Wilcoxon test was applied for those tests and scales that showed statistical significance in the Friedman test ( $\mathrm{p} \leq 0.05)$. The results showed more statistical associations for variables related to independent living, which can compromise quality of life.

Table 3 - Statistically significant tests and scales among the case group and the control groups

\begin{tabular}{lcccc}
\hline & & \multicolumn{3}{c}{ Wilcoxon test } \\
\cline { 3 - 5 } Variables & $\begin{array}{c}\text { Friedman } \\
\text { test }\end{array}$ & $\begin{array}{c}\text { Case Group } \\
\text { x Control } \\
\text { Group 1 }\end{array}$ & $\begin{array}{c}\text { Case Group } \\
\text { x Control } \\
\text { Group 2 }\end{array}$ & $\begin{array}{c}\text { Case Group } \\
\text { x Control } \\
\text { Group 3 }\end{array}$ \\
\hline Barthel Index & 0.001 & 0.819 & 0.008 & 0.002 \\
Instrumental Activity of & 0.001 & 0.916 & 0.032 & 0.005 \\
Daily Living & 0.000 & 0.614 & 0.001 & 0.001 \\
Tinetti Scale & & & & 0.004 \\
Geriatric Depression & 0.003 & 0.431 & 0.003 & 0.021 \\
Scale & & & & 0.053 \\
Right grip strength & 0.042 & 0.609 & & 0.003 \\
\hline
\end{tabular}


The characteristics of fall occurrence were similar between the groups. Falls occurred more often in the morning (56.5\%), in a lighted environment (76.7\%), in places without handrails (93.3\%), ramps $(96.6 \%)$ and in cluttered environments $(86.6 \%)$. The falls more often occurred on a rough and dry floor (76.7\%), and the most common footwear worn was rubber flip flops (50.3\%). Half of the participants did not use anti-slip material in the bathroom, and only one person mentioned the use of rugs. The elderly people with stroke fell more at their houses (60.0\%), particularly in the bathroom and kitchen (33.3\%). By contrast, the elderly without stroke fell more outside their home (73.3\%), including public places such as sidewalks, parks or bus stations.

\section{Discussion}

The limitations of this study were the small size of the sample, which can decrease the generalization of the findings, and the cross-sectional design, that is limited to investigate the event at only one point in time. Additionally, the common cognitive problems in the elderly population may have introduced bias because the participants were asked to recall previous data, which can result in incorrect information about the risk factors for falls.

Also, a longitudinal design and the adoption of daily notes taken by participants regarding the risk factors experienced are recommended for future studies. In addition, extrinsic conditions should be assessed through home visits to evaluate the reliability of the data gathered and include elderly people who are more dependent and unable to move.

The findings of the current study are supported by other authors who found out that falls among the elderly were experienced mostly by females living at home ${ }^{(12)}$. Falls affect all demographic groups and occur even among elderly who have support. They also occur primarily at home (74.0\%), indoors $(75.0 \%)$ and during non-vigorous activities such as walking (58.0\%), and these tended to affect the oldest elderly people. Meanwhile a significant number of falls occurring outdoors in public locations usually take place during more vigorous activity ${ }^{(13)}$.

In this study, most of the falls by the group without stroke occurred outdoors, whereas those with stroke primarily fell at home. This most likely occurred due to sequelae of stroke, which resulted in more dependence and made walking a more difficult activity for these people.

Participants who reported falls in a post-stroke rehabilitation program had worse upper and lower extremity motor control compared with those who did not fall. Additionally, they had worse proprioceptive conditions, the most uncomfortable and slowest walking and the worst performance on mobility tests. These findings occurred due to the highest overall disability of the people who reported falls, and they indicate that incidence of falls is high even for individuals who are in a rehabilitation program focused on improving mobility, balance and walking ${ }^{(14)}$. Nevertheless, Table 1 shows that the groups with participants that had a stroke had overall increased risk factors for falls, while the control group 2, with people that also had a fall episode recently, had slightly less contributing factors. Additionally, the control group 3, without falls or stroke was the healthiest of the groups.

Furthermore, this study also found out that the use of antihypertensive and angiotensin-converting enzyme inhibitors were statistically significant among some groups as shown in Table 2. In general, these medications are used as a preventive strategy to avoid stroke recurrence. However, according to other authors, these medications increase the risk of falls due to adverse reactions such as cramping, muscle weakness, dizziness and orthostatic hypotension, which may alter the mechanisms of gait and balance ${ }^{(10)}$.

Variables related to mobility, such as decreased strength in lower extremities, impaired gait and low performance on gait and balance tests, demonstrated statistical significance, particularly in the case group as presented in Table 2. Indeed, the elderly who reported falls and strokes presented more dependence 
to perform general and instrumental activities of daily life.

Impaired physical mobility can also be worsened by foot changes, such as foot deformities, corns and calluses, hallux deformities, mallet toes, flat feet and edema, can lead to functional gait limitations. Foot changes can increase the risk of falls and should be continuously assessed since it demonstrated statistical significance among the participants of case group and control group 3, as shown in Table 2 .

Also, as shown in Table 3, statistical significance was realized in relation to the right-hand grip strength significantly differed between the case group and the control group without stroke and falls $(p=.021)$. This finding highlights the relevance of measuring the strength of both hands separately.

Thus, the physical limitations due to a stroke affect the activities of daily living, and the likelihood of having at least one fall increases progressively with the severity of limitation of these activities. Moreover, people with inability to perform instrumental activities of daily living were more likely to fall indoors, and the risk of falling appeared to be greatest for those whose homes lacked accessibility features to prevent falls ${ }^{(15)}$.

The proprioceptive system also demonstrated statistical association when comparing the groups with falls. This system requires visual functioning for posture control. A systematic analysis has shown that impaired vision, particularly poor depth perception and low-contrast visual acuity, are risk factors for falls and recurrent falls ${ }^{(16)}$.

Using logistic regression, another study has demonstrated that elderly people who had experienced falls have worse physical function (Barthel), standing balance and cognition, and that they took more medications. Furthermore, the same group had a higher prevalence of falls in the last months and was more likely to use a walking aid ${ }^{(12)}$.
In this study, the groups with falls had an average of more than one fall per person. This finding implies that the recurrence of falls is strongly associated with a new event of fall during the hospitalization or rehabilitation period. This data is corroborated by a study that says that most seniors have falls in the previous year, and as a person ages their susceptibility to the occurrence of this event increases considerably, especially on those with comorbidities or complications as a stroke ${ }^{(17)}$.

In the context of the extrinsic factors, after a stroke, patients require home accessibility changes to adapt their environment to their disabilities. Fall prevention should focus on risk at home, particularly in the early months post-stroke, and should include multifactorial risk assessment and management concomitant with interventions to improve walking and mobility ${ }^{(13)}$.

In addition, the primary care workforce focused on communities is important due to its involvement with patient education focused on fostering lifestyle changes and promoting strategies for improving the level of mobility in community-dwelling older adults $^{(13)}$.

Finally, the findings of this study suggest the following clinical implications: the intrinsic risk factors were highly associated to the occurrence of falls, and an episode of stroke increases the statistical significance among the groups without this condition. Moreover, it contributes to a better prioritization of nursing actions towards patients or residents who have had a stroke. Knowing that patients after a stroke are more prone to falls leads to the importance of preventive measures, which also reflect the quality of care provided. Thus, planning home visits and focusing on patient's safety are examples of how health professionals can assess and prevent this problem. 


\section{Conclusion}

The stroke is associated with falls and the intrinsic factors presented greater statistical correlations, supporting the hypothesis that many factors influence the occurrence of falls, indicating the importance of nurses attempting the early detection and assessment of the intrinsic risks present in each elderly patient. Especially on those patients that had a stroke, since their physical sequelae can have greater influence on falls.

\section{Collaborations}

Costa AGS, Oliveira-Kumakura ARS and Lopes MVO contributed with the conception and project, analysis and interpretation of data. Castro NB contributed with writing the article. Araujo TL and Martins VS contributed with the relevant critical review of the intellectual content and with the final approval of the version to be published.

\section{References}

1. Day JR, Ramos LC, Hendrix CC. Fall prevention through patient partnerships. Nurse Pract. 2012; 37(7):14-9. doi: http://dx.doi.org/10.1097/01. NPR.0000415241.08343.1c

2. Reuben DB, Herr KA, Pacala JT, Pollock BG, Potter JF, Semla TP. Geriatrics at your Fingertips. New York: The American Geriatrics Society; 2012.

3. Batchelor FA, Mackintosh SF, Said CM, Hill KD. Falls after stroke. Int J Stroke. 2012; 7(6):48290. doi: http://dx.doi.org/10.1111/j.17474949.2012.00796.x

4. Lima ACMACC, Silva AL, Guerra DR, Barbosa IV, Beerra KC, Oriá MOB. Nursing diagnoses in patients with cerebral vascular accident: an integrative review. Rev Bras Enferm. 2016; 69(4):78592. doi: http://dx.doi.org/10.1590/00347167.2016690423i
5. Vieira ER, Freund-Heritage R, Costa BR. Risk factors for geriatric patient falls in rehabilitation hospital settings: a systematic review. Clin Rehabil. 2011; 25(9):788-99. doi: http://dx.doi. org/10.1590/S0080-623420140000300021

6. Morais HCC, Holanda GF, Oliveira ARS, Costa AGS, Ximenes CMB, Araujo TL. Identificação do diagnóstico de enfermagem "Risco de quedas em idosos com acidente vascular cerebral”. Rev Gaúcha Enferm. 2012; 33(2):117-24. doi: http://dx.doi. org/10.1590/S1983-14472012000200017

7. Herdman TH. NANDA International nursing diagnoses: definitions and classification, 20122014. Oxford: Wiley-Blackwell; 2012.

8. Smeltzer SC, Bare BG. Tratado de enfermagem médico cirúrgica. Rio de Janeiro: Guanabara Koogan; 2015.

9. Ministério da Saúde (BR). Manual de rotinas para atenção ao AVC [Internet]. 2013 [citado 2016 nov. 20]. Disponível em: http://bvsms.saude.gov.br/ bvs/publicacoes/manual_rotinas_para_atencao_ avc.pdf

10. Oliveira ARS, Costa AGS, Araujo TL, Aquino OS, Pinheiro AKB, Ximenes LB. Competências essenciais de programas de assistência domiciliar para pacientes com acidente vascular cerebral. Rev Eletr Enf [Internet]. 2013 [citado $2016 \mathrm{dez}$. 10]; 15(2):317-25. Disponível em: https://www. fen.ufg.br/fen_revista/v15/n2/pdf/v15n2a02. pdf

11. Oliveira CR, Pagliarin, KC, Calvette LF, Bastos AS, Fonseca RP. Communicative processing in adults with unilateral right hemisphere stroke: assessment by means of a short battery. Act Colom Psicol. 2016; 19(2):73-82. doi: http://dx.doi. org/10.14718/ACP.2016.19.2.4

12. Whitney J, Close JCT, Lord SR, Jackson SH. Identification of high risk fallers among older people living in residential care facilities: a simple screen based on easily collectable measures. Arch Gerontol Geriatr. 2012; 55(3):690-5. doi: https:// doi.org/10.1016/j.archger.2012.05.010 
13. Landy DC, Mintzer MJ, Dearwater SR, Graygo JA, Schulman CI. Fatal falls in an ethnically diverse urban community: the link between demographic factors and the circumstances surrounding fatal falls. South Med J. 2012; 105(8):405-10. doi: https://doi.org/10.1097/SMJ.0b013e31825efc70

14. Tilson JK, Wu SS, Cen SY, Feng Q, Rose DR, Behrman $\mathrm{AL}$, et al. Characterizing and identifying risk for falls in the LEAPS study. Stroke 2012; 43(2):446-52. doi: https://doi.org/10.1161/ STROKEAHA.111.636258

15. Henry-SánchezJT, KurichiJE, Xie D, Pan Q, Stineman MG. Do elderly people at more severe activity of daily living limitation stages fall more? Am J Phys Med Rehabil. 2012; 91(7):601-10. doi: https:// doi.org/10.1097/PHM.0b013e31825596af
16. Salonen L, Kivela S-L. Eye diseases and impaired vision as possible risk factors for recurrent falls in the aged: a systematic review. Curr Gerontol Geriatr Res. 2012; 2012:271481. doi: http:// dx.doi.org/10.1155/2012/271481

17. Lima DWC, Cruz AMM, Morais FMP, Torres ADM, Freitas MC. Impact of a fall in the elderly: an analysis of the risk factors. Rev Rene [Internet]. 2013 [cited 2017 Aug. 10]; 14(5):929-37. Available from: http://www.revistarene.ufc.br/ revista/index.php/revista/article/view/1194/ pdf_1 